6008

Research Article

Journal of Extension Education

Vol. 30 No. 1, 2018

DOI:https://doi.org/10.26725/JEE.2018.1.30.6008-6013

\title{
Extent of Adoption of House terrace Cultivation of Urban dwellers of Thiruvananthapuram Corporation, Kerala
}

\author{
Greeshma Udayan ${ }^{1}$ and G. S. Sreedaya ${ }^{2}$
}

\begin{abstract}
This paper assesses the adoption of recommended practices for house terrace cultivation in Thiruvananthapuram Corporation of Kerala by the urban dwellers. Majority of the urban dwellers came under medium level of adoption of recommended practices for house terrace cultivation of Kerala Agricultural University. With respect to Rogers' adoption curve, categorisation of respondents was done on the basis of adoption of the recommended practices for house terrace cultivation of Kerala Agricultural University The results revealed that there was high percentage of respondents in the early adopter category.
\end{abstract}

Keywords : House terrace cultivation; Extent of adoption; Urban dwellers; Kerala Agricultural University; Recommended practice; Adopter categories; Kerala.

\section{INTRODUCTION}

House terrace cultivation had existed since the days of Babylon in $2300 \mathrm{BC}$; today the concept has gained momentum in India due to population explosion and shrinkage of cultivable lands, The indiscriminate use of pesticides in the state and the increased dependence on imported vegetables from neighbouring states having a junk of synthetic chemicals, has resulted in the increase of cancer patients in Kerala (Krishnakumar, 2016). Despite having good rainfall and sunlight, the state produces only 30-40 percent of its vegetable requirement. In order to confront the growing demand for food, the development of diverse agricultural production system in and around cities get activated by exploring the vacant places in cities like house or flat terraces and balconies.

In view of its benefits and potential to contribute food and nutrition security, income generation and poverty alleviation, the present study was carried out among the urban dwellers, the new generation of farmers, of Thiruvananthapuram Corporation, Kerala on the extent of adoption of the recommended practices for house terrace cultivation of Kerala Agricultural University.

\section{METHODOLOGY}

The study was conducted in Thiruvananthapuram Corporation of Kerala where house terrace cultivation is very popular. Many government initiatives are

1. Research Associate (Agricultural Extension) \& 2. Assistant professor (Sr: scale), Department of Agricultural Extension, College of Agriculture, Vellayani, Thiruvananthapuram, Kerala.

Received : 15-03-2018; Accepted : 12-05-2018 
successfully running in Thiruvananthapuram Corporation for the augmentation of house terrace cultivation. Six wards namely Kazhakuttom, Kudappanakunnu, Nemom, Vizhinjam, Kadakampally and Poojappura from Thiruvananthapuram Corporation were randomly selected. From each of these selected wards, 20 respondents were randomly selected having a total of 120 respondents. The respondents of the study were the members of urban households involved in house terrace cultivation. A structured pretested interview schedule was developed to measure the adoption of recommended practices for house terrace cultivation.

A list of practices recommended for house terrace cultivation by Kerala Agricultural University was given to the experts. Based on their perception, sixteen practices having higher scores were selected for determining adoption index. The respondents were asked to indicate their responses on the selected sixteen practices recommended for house terrace cultivation. The data collected from the respondents were scored, tabulated and analysed using statistical methods. The statistical tools like frequency and percentage were employed for the data interpretation. The adoption index was worked out with the help of formula given by Jaganathan (2004) as mentioned below:

The respondents were categorised

\section{Adoption index $\quad=\quad \frac{\text { Respondent's total score }}{\text { Total possible score }} \times 100$}

into different adopter categories based on the adoption of recommended practices on house terrace cultivation as explained by Rogers (1983) namely, innovators, early adopters, early majority, late majority and laggards. Normally, the noncumulative adopter distribution takes the form of a bell-shaped curve. Consequently, using two statistical parameters of the bell shaped curve -mean time of adoption of practices $(\mathrm{m})$ and its standard deviation $(\sigma)$-provides the five adopter categories and categorised as follows

\begin{tabular}{|r|l|c|r|}
\hline $\begin{array}{r}\text { Sl. } \\
\text { No. }\end{array}$ & \multicolumn{1}{|c|}{ Adopter category } & $\begin{array}{c}\text { Percentage of } \\
\text { adopters (\%) }\end{array}$ & $\begin{array}{r}\text { Area covered under } \\
\text { normal bell shaped curve }\end{array}$ \\
\hline 1 & Innovators & 2.5 & Beyond $\mathrm{m}-2 \boldsymbol{\sigma}$ \\
\hline 2 & Early Adopters & 13.5 & Between $\mathrm{m}-\boldsymbol{\sigma} \& \mathrm{~m}-2 \boldsymbol{\sigma}$ \\
\hline 3 & Early Majority & 34 & Between $\mathrm{m} \& \mathrm{~m}+\sigma$ \\
\hline 4 & Late Majority $\sigma$ & $\boldsymbol{m}$ \\
\hline 5 & Laggards & 34 & Beyond $\mathrm{m}+\boldsymbol{\sigma}$ \\
\hline
\end{tabular}


FINDINGS AND DISCUSSION

The distribution of recommended practices based on the respondent's adoption regarding house terrace cultivation is depicted in Table 1.

Table 1.

\section{Adoption of Recommended practices for House terrace Cultivation}

$(n=120)$

\begin{tabular}{|c|c|c|c|}
\hline SI. No. & Practices & $\begin{array}{l}\text { Adopted } \\
\text { (No.) }\end{array}$ & $\begin{array}{l}\text { Percentage } \\
\text { (\%) }\end{array}$ \\
\hline 1 & Potting mixture is soil, sand and cow dung in 2:1:1 ratio & 115 & 95.83 \\
\hline 2 & Kitchen waste is used as manures & 81 & 67.50 \\
\hline 3 & To reduce the pest incidence, botanical pesticides are used & 80 & 66.67 \\
\hline 4 & $\begin{array}{l}\text { Pest and disease incidence are reduced by collecting and } \\
\text { destructing the pest (eggs, larvae, pupae) and disease affected } \\
\text { plants. }\end{array}$ & 70 & 58.33 \\
\hline 5 & Drip irrigation is used to increase the water use efficiency. & 57 & 47.5 \\
\hline 6 & $\begin{array}{l}\text { The position of bricks and sacks, after each cultivation are } \\
\text { changed. }\end{array}$ & 68 & 56.67 \\
\hline 7 & $\begin{array}{l}\text { To prevent water leakage on the building, sacks are placed on } \\
\text { bricks. }\end{array}$ & 66 & 55.00 \\
\hline 8 & Hand sprayer is used for foliar application & 61 & 50.83 \\
\hline 9 & Bio-control agents are used to reduce the pest incidence. & 51 & 42.50 \\
\hline 10 & $\begin{array}{l}\text { To improve the water holding capacity, coir pith is used as } \\
\text { growing medium. }\end{array}$ & 29 & 24.17 \\
\hline 11 & Crop rotation with pulse crop in each sack. & 23 & 19.17 \\
\hline 12 & Poultry rearing integrated with terrace cultivation & 10 & 8.33 \\
\hline 13 & Crops are raised in hydroponics method. & 6 & 5.00 \\
\hline 14 & $\begin{array}{l}\text { For proper limited space utilization, vertical garden structures } \\
\text { are used. }\end{array}$ & 5 & 4.17 \\
\hline 15 & Azolla cultivation practised & 0 & 0.00 \\
\hline 16 & $\begin{array}{l}\text { To enrich the nutrients in growing media, PGPR (Plant Growth } \\
\text { Promoting Rhizobacteria) mix I is applied. }\end{array}$ & 0 & 0.00 \\
\hline
\end{tabular}


From Table 1, it is clear that the practices 'use of potting mixture with soil, sand and cow dung in the ratio of 2:1:1', 'use of kitchen wastes as manures' and 'application of botanical pesticides to reduce the pest incidence' were ranked 1, 2 and 3 respectively, by the respondents. It is interesting to note that, 'azolla cultivation' and 'application of PGPR (Plant Growth Promoting Rhizobacteria) mix I' were not adopted by the respondents. It might be due to the fact that the extension agencies gave less orientation to respondents towards these practices and hence they were unaware about the possibility and benefit of using these practices.

Table 2.

Distribution of Respondents based on the Extent of adoption of Recommended practices for House terrace cultivation

$(n=120)$

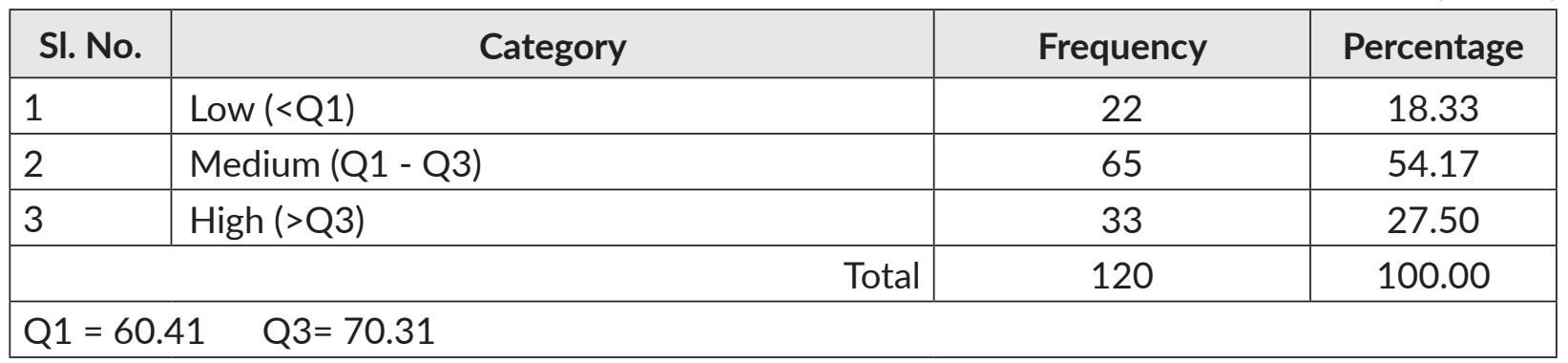

It is clear from Table 2 that 54.17 per cent of the respondents belonged to medium category, 27.50 per cent in the high category and 18.33 per cent in the low category of extent of adoption of practices recommended on house terrace cultivation. Majority of the respondents came under medium category and this might be due to their access to knowledge and emerging technology. The outcome of the technology transfer is the respondent's adoption and bringing that into practice. The results are similar to the findings of Bandole (2011).

Table 3.

Categorisation of Respondents based on Adoption of Recommended practices on House terrace cultivation of Kerala Agricultural University

$(n=120)$

\begin{tabular}{|c|l|l|l|l|l|}
\hline $\begin{array}{c}\text { Sl. } \\
\text { No. }\end{array}$ & \multicolumn{1}{|c|}{ Category } & \multicolumn{1}{|c|}{ Score range } & Frequency & $\begin{array}{c}\text { Percentage of } \\
\text { respondents }\end{array}$ & $\begin{array}{c}\text { Rogers's standard } \\
\text { curve (\%) }\end{array}$ \\
\hline 1. & Innovators & $<48.91$ & 2 & 1.67 & 2.50 \\
\hline 2. & Early adopters & $48.91-56.72$ & 26 & 21.67 & 13.50 \\
\hline 3. & Early majority & $56.73-64.54$ & 41 & 34.16 & 34.00 \\
\hline 4. & Late majority & $64.55-72.35$ & 34 & 28.33 & 34.00 \\
\hline 5. & Laggards & $>72.35$ & 17 & 14.17 & 16.00 \\
\hline & Total & & 120 & 100 & 100 \\
\hline
\end{tabular}


The urban farmers of Thiruvananthapuram Corporation were categorised into different adopter categories as explained by Rogers (1983) namely, innovators, early adopters, early majority, late majority and laggards.

1 - Innovators, 2 - Early adopters, 3 - Early majority, 4 - Late majority, 5 - Laggards

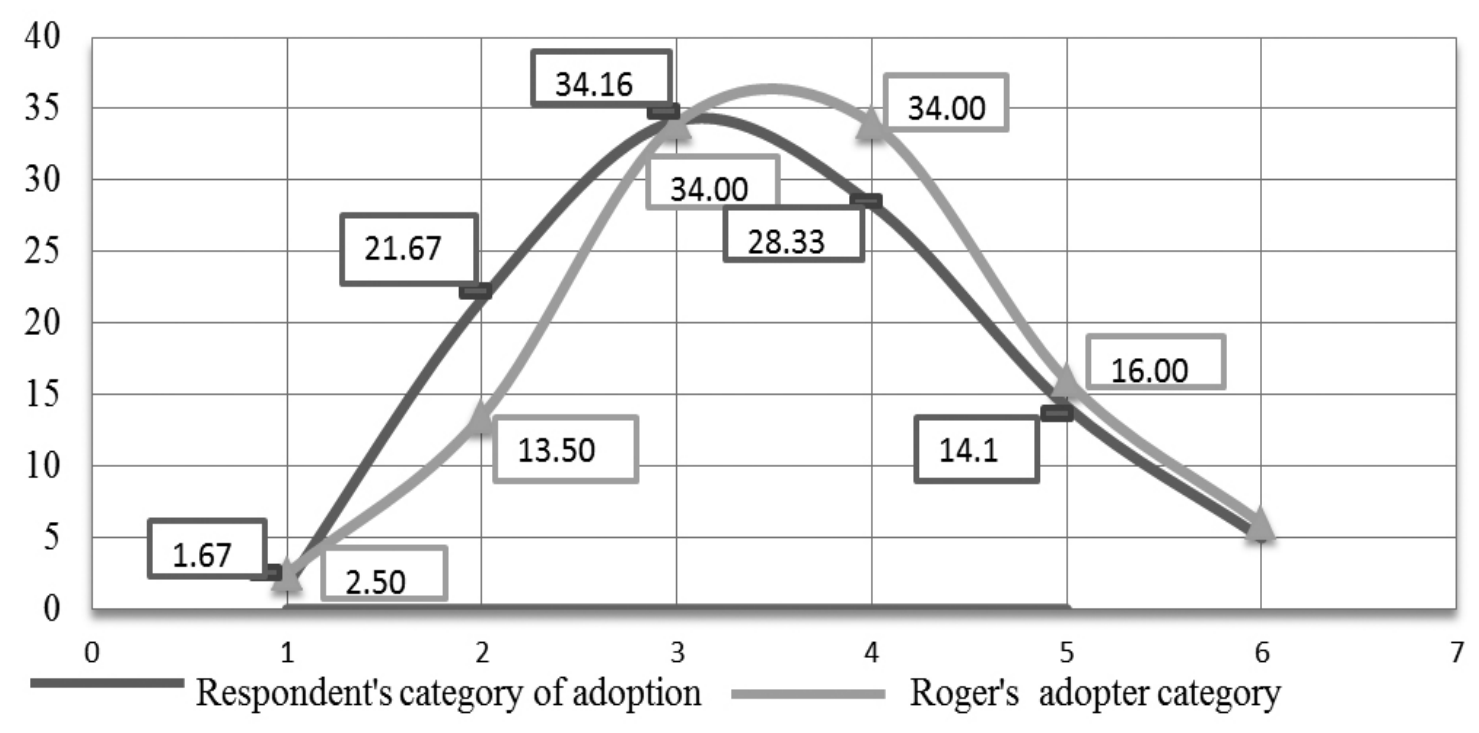

Fig. 1. Categorisation of respondents based on adoption of recommended practices on house terrace cultivation with respect to Rogers' adoption curve

Table 3 and Fig. 1 depict the categorisation of respondents based on adoption of recommended practices on house terrace cultivation with respect to Rogers' adoption curve. It is clear that the percentage of innovators was 1.67 per cent where as it was 2.5 per cent for the standard Rogers curve. From this, it can be inferred that the respondents tend to take no risk voluntarily and considering their hectic schedules and life styles, most of the urban dwellers preferred technologies that were established and accepted so that time spent on trial and error of new technologies could be reduced. Early adopters were 21.67 per cent which is greater than 13.5 per cent of the Rogers curve which may be due to the respondents' higher social status and increased knowledge on importance of vegetable consumption and environmental benefits of house terrace cultivation. Early majority were 34.16 per cent which is in conformation with 34 per cent of the standard Rogers' curve which might be due to their contact with early adopters. Late majority were 28.33 per cent and laggards constituted 14.17 per cent which is less than 34 per cent and 16 per cent of the Rogers' curve respectively. This might be due to the cosmopoliteness attribute of the people living in cities and they widely adopt majority of the 
practices which are accepted by their social network. The high percentage of respondents in early adopters is a good indication of adoption of recommended practices on house terrace cultivation.

\section{CONCLUSION}

The study revealed that the majority of the respondents came under medium category of adoption and had high percentage of respondents in early adopters' category. However the practices viz., 'azolla cultivation' and 'application of PGPR (Plant Growth Promoting Rhizobacteria) mix I' were not adopted by the respondents. This non adoption of the practices indicates that lack of awareness and technical knowledge on these practices by the urban dwellers. Hence these practices require much more spread among the growers. The policy makers should give due consideration to this new generation of farmers as urban farming will soon conquer the face of Indian agriculture.

\section{REFERNCES}

Bandole, S. (2011). A study on awareness and adoption of post-harvest management practices in maize among the farm women in Khargone district of Madhya Pradesh. Unpublished M.Sc. (Ag.) thesis, Rajmata Vijayaraje Scindia Krishi Vishwavidyalaya, Gwalior, 109p.

Jaganathan, D. (2004). Analysis of organic farming practices in vegetable cultivation in Thiruvananthapuram district, Unpublished M.Sc. (Ag.) thesis, Kerala Agricultural University, Thrissur. 132p.

Krishnakumar M. K. (2016). Health crisis in Kerala: The increase in cancer, kidney and liver diseases. The Economic Times, 23 April 2016, p.16.

Rogers, E. M. (1983) Diffusion of innovations ( $3^{\text {rd }}$ Ed.). The Free Press, New York.460p. 